\title{
Investigation of the Tidal Character in Bawean Island East Java Using Admiralty Method
}

\section{Investigasi Karakter Pasang Surut di Pulau Bawean Jawa Timur menggunakan Metode Admiralty}

\author{
Luhur Moekti Prayogo $^{1 *}$ dan Muhammad Hanif ${ }^{2}$ \\ ${ }^{1}$ Marine Science Study Program, Faculty of Fisheries and Marine, Universitas PGRI Ronggolawe, \\ Tuban, East Java, 62381 \\ ${ }^{2}$ Department of Geography, State University of Padang, Padang, 25132, Indonesia \\ *email: luhur.moekti.prayogo@unirow.ac.id
}

Received

31 August 2021

Accepted

12 January 2022

\section{Abstract}

Bawean Island is one of the islands in Gresik Regency, East Java, where almost all its territory is a coastal environment. This region's tidal oceanographic condition is critical because this area has a lot of potential for marine tourism and relatively shallow waters. This study aims to determine the tidal characteristics in the waters of Bawean Island, East Java, using the Admiralty method. This method was chosen because it can calculate the tidal component with only 15 days of data and can be used in various water conditions. The data used is tidal data from the Geospatial Information Agency (BIG) on November 1-15, 2020. From this research, it can be concluded that tidal analysis using the Admiralty method produces nine components, including M2, S2, N2, K1, O1, P1, M4, MS4, and K2. The four components determine the type of tide, namely $\mathrm{O} 1, \mathrm{~K} 1, \mathrm{M} 2$, and $\mathrm{S} 2$, with amplitude values of $11.79347,30.14857,55.72241$, and 63.69851. The calculation with the Formzahl number equation yields a value of $0.3512(0.25<\mathrm{F}$ $<1.5)$, which means that the tidal type in Bawean Island, East Java, has a mixed type with a semidiurnal tendency (double daily).

Keyword: Tides, Admiralty, Formzahl, Semidiurnal, Bawean Island

\begin{abstract}
Abstrak
Pulau Bawean adalah salah satu pulau yang terletak di Kabupaten Gresik, Jawa Timur yang hampir seluruh wilayahnya adalah lingkungan pesisir. Kondisi oseanografi pasang surut wilayah ini sangat penting untuk diketahui dikarenakan kawasan ini memiliki banyak potensi wisata bahari dan perairan yang relative dangkal. Penelitian ini bertujuan untuk mengetahui karakteristik pasang surut di perairan Pulau Bawean, Jawa Timur menggunakan metode Admiralty. Metode ini dipilih karena dapat menghitung komponen pasang surut dengan data hanya 15 hari dan dapat digunakan dalam berbagai kondisi perairan. Data yang digunakan merupakan data pasang surut dari Badan Informasi Geospasial (BIG) pada tanggal 1-15 November 2020. Dari penelitian ini dapat disimpulkan bahwa analisis pasang surut menggunakan metode Admiralty menghasilkan sembilan komponen diantaranya M2, S2, N2, K1, O1, P1, M4, MS4 dan K2. Keempat komponen merupakan penentu tipe pasang surut yaitu O1, K1, M2 dan S2 dengan nilai amplitudo secara berturut-turut sebesar 11.79347, 30.14857, 55.72241 dan 63.69851. Perhitungan dengan persamaan bilangan Formzahl dihasilkan nilai sebesar $0.3512(0,25<\mathrm{F}<1,5)$, yang berarti bahwa tipe pasut di Pulau Bawean Jawa Timur memiliki tipe campuran dengan kecenderungan Semidiurnal (Harian Ganda).
\end{abstract}

Kata Kunci: Pasang Surut, Admiralty, Formzahl, Semidiurnal, Pulau Bawean 


\section{Introduction}

Bawean Island is one of the islands located in Gresik Regency, East Java Province, where almost all of its territory is coastal. This island is located in the middle of the sea, which is about 80 nautical miles (Sukandar $e t$ al., 2017). Bawean Island has about $196.27 \mathrm{~km}$ with a population of about 70,000 people who occupy two subdistricts, namely Sangkapura and Tambak (East Java Government, 2015). The geographical location of this island is at $05^{\circ} 76^{\prime} 49.54^{\prime \prime}$ to $05^{\circ} 87^{\prime} 13.43^{\prime \prime}$ South Latitude and $112^{\circ} 56^{\prime} 90.92^{\prime \prime}$ to $112^{\circ} 77^{\prime} 63.14^{\prime \prime}$ East Longitude with a total of 30 villages (Marine and Fisheries Ministry, 2016).

This area's tidal oceanographic condition is critical because one of the accesses to the site is to use sea transportation, where this information will determine ship operations. Tides are a natural phenomenon of the periodic rise and fall of sea levels caused by the gravitational force of the moon, sun, and earth (Triatmodjo, 2012). This phenomenon is widespread in coastal and marine environments, so it indirectly affects the activities of people's lives. Tides are one of the hydro-oceanographic parameters that can also affect fisheries, transportation, coastal area profiles, fish farming, and the aquaculture industry that enters seawater into ponds at high tide (Hamunaet al., 2018, Dwikarsa, 2021).

Various natural factors undoubtedly influence the tides that occur in the sea. Ongkosongo (1989) states that the factors that influence the tidal phenomenon include (1) the earth rotation with a period of 24 hours, (2) the revolution of the earth with a period of 365.25 days, and (3) the revolution of the moon to the earth with a period of 29.5 days. In addition, other factors besides celestial bodies can affect tides, including the topography of the sea and the bay environment, which causes different types of tides between regions. According to Ongkosongo (1989), three types of tidal types occur, including diurnal (one tide occurs a day), semidiurnal (two tides occur a day), and mixed type (two tides occur in a day with significant differences).

Today, there are two standard methods for calculating tides, including Least Square and Admiralty. The Least Square method is a tidal calculation method that minimizes the elevation equation to obtain a simultaneous calculation equation. At the same time, the Admiralty method is a method for calculating harmonic components that refers to the provisions of tables 1 and 2 (Khotip et al., 2016). The advantage of this method is that it can calculate the tidal component with only half a month (15 days) of data and can be used in various water conditions.

Research on tides using various Admiralty methods has been carried out by Supriyadi et al. (2019) in Pameungpeuk, Belitung, and Sarmi Waters. The study resulted that the waters of Pameungpeuk, Belitung have mixed types and tend to be double daily. Meanwhile, Sarmi waters have a single daily type. Then the study resulted in the highest sea level of $3.59 \mathrm{~m}$ and the lowest of $1.70 \mathrm{~m}$. Furthermore, Novian Sangkop \& Mamoto (2015) research used the Admiralty method at Bulo Beach, Minahasa Regency. The purpose of this study was to determine the elevation and types of tides on Bulo Beach. The study resulted that the highest elevation was 145 $\mathrm{cm}$ and the lowest was $3 \mathrm{~cm}$. The type of tide at Bulo Beach is Mixed lean-to Double Daily.

The research of Fitriana et al. (2019) uses the Admiralty method to determine the type of tide in the tidal station area of the Geospatial Information Agency (BIG), which is $50 \mathrm{~km}$ between stations. The research resulted that the tidal type between station locations had the same type. Then Korto's (2015) research conducted at Nuangan Beach used the Admiralty method. The study resulted that the tidal type at Nuangan Beach was Mixed to Double Daily with the highest elevation of $85 \mathrm{~cm}$ and the lowest of $2 \mathrm{~cm}$. Then the research of Nurisman et al. (2012) used the Admiralty method to determine the type and pattern of tidal propagation in the Musi River Shipping. This research found that the tidal type was single daily with a propagation pattern of 5 hours 20 minutes at low tide and 4 hours 30 minutes at high tide.

From the explanation above, this study aims to determine and analyze the types of tides in the waters around Bawean Island, Gresik Regency, East Java using the Admiralty method. This research is critical because there is no tidal analysis using the Admiralty method in the area. The information obtained can later be used to manage and develop coastal areas, especially in Bawean Island, East Java.

\section{Material and Method}

\subsection{Research Location}

This research was conducted on November 1-15, 2020, using 15 days of data. The tidal location is at coordinates 05 43'26" South Latitude and 112 36'39" East Longitude, in Bawean Island, Gresik Regency, East Java. Tidal observation data was obtained from the Geospatial Information Agency (BIG), which has an interval of one hour. Figure 1 is a map of the research location sourced from ESRI World Imagery.

\subsection{Admiralty Method}

The Admiralty method is a method for calculating tides with a short data range, namely 15 piantan and 29 piantan (Fitriana et al., 2019). AT Doodson invented this method in 1921 for a Hydrographic ffice, British Admiralty. According to Pariwono (1989), the Admiralty method only produces nine components and calculates 
data with a short range. Ahmad et al. (2017); Fitriana et al. (2019) states that the calculation of tides using the Admiralty method uses a supporting table that contains the value of the calculation constants

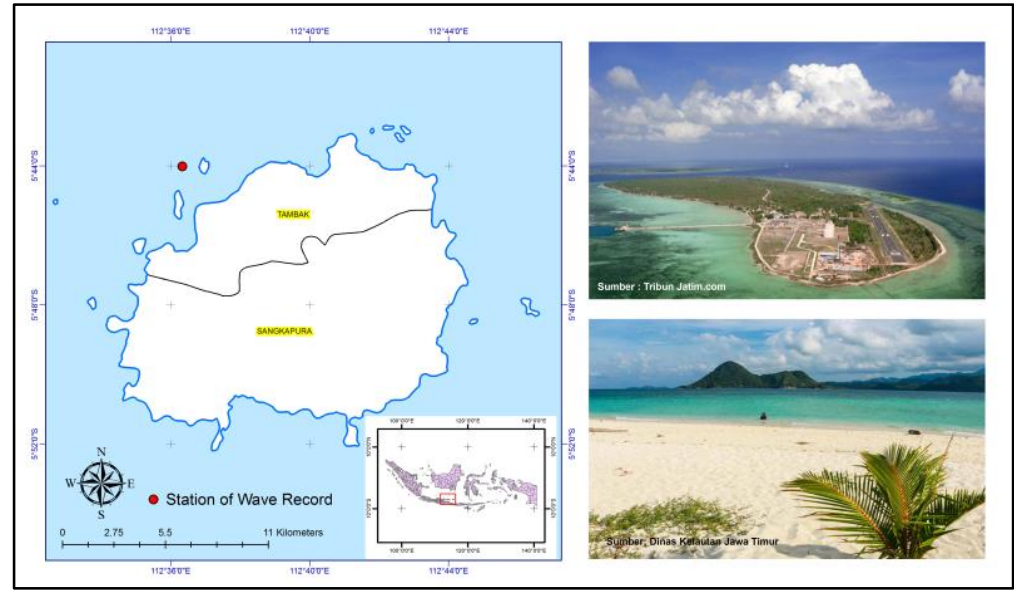

Figure 1. Research location in Bawean Island, Gresik Regency, East Java

\subsection{Tidal Harmonic Component}

Tides are the process of rising and falling sea levels that occur periodically and can be predicted (Ongkosongo, 1989). Tidal constants are harmonic with time, so they are called tidal harmonic constants (Table $1)$.

Table 1. Tidal Harmonic Components

\begin{tabular}{cccc}
\hline Tidal Type & Symbol & Angular Speed (\% hour) & Period (hour) \\
\hline \multirow{3}{*}{ Semi diurnal } & M2 & 28,9841 & 12,42 \\
& S2 & 30,000 & 12,00 \\
& N2 & 28,4397 & 12,66 \\
Diurnal & K2 & 30,0821 & 11,97 \\
& O1 & 15,0411 & 23,93 \\
& P1 & 13,9430 & 25,82 \\
Long Period & Mf & 14,9589 & 24,07 \\
& Msf & 1,0980 & 327,86 \\
& Mm & 1,0159 & 354,36 \\
Shallow Water & Ssa & 0,5444 & 661,30 \\
& M4 & 0,0821 & 4384,90 \\
& MS4 & 59,97 & 6,21 \\
\end{tabular}

Source: (De Jong et al., 2002)

\subsection{Tidal Harmonic Component}

Determination of the tidal type can be seen from the resulting Formzahl number. There are central components in determining tidal types, including O1, K1, M2 and S2. Equation 1 shows the Formzahl number in tidal calculations (Triatmodjo, 2009).

Where:

$$
\mathrm{F}=\frac{(\mathrm{O} 1+\mathrm{K} 1)}{(\mathrm{M} 2+\mathrm{S} 2)}
$$

$\mathrm{F} \quad=$ Number Formzahl

O1 = Constant affected by the declination of the moon

$\mathrm{K} 1=$ Constants affected by the declination of the moon and sun

M2 = Constants that are affected by the position of the moon

S2 = Constant which is affected by the position of the sun

Determination of the tidal type can refer to the range of values (Table 2).

\begin{tabular}{cc} 
& Table 2. Tidal Type \\
\hline Value & Tidal Type \\
\hline $\mathrm{F} \leq 0.25$ & Semidiurnal \\
$0.25<\mathrm{F} \leq 1.5$ & Mixed, tend to be semi-diurnal \\
$1.50<\mathrm{F} \leq 3.0$ & Mixed, tend to be diurnal \\
$\mathrm{F}>3.0$ & Diurnal \\
\hline Source: (Oktavia et al., $2011 ;$ Hasibuan et al., 2015)
\end{tabular}




\section{Result and Discussion}

\subsection{Admiralty Method}

In this study, tidal observations used were data from BIG. The data consists of 15 days starting from November 1-15, 2020, with one-hour intervals. Calculation of tides using the Admiralty method is divided into eight schemes that refer to (Fadilah et al., 2014). The first scheme aims to perform smoothing on tidal data obtained from BIG and included in the table. The table contains information about the time and date, namely November 1-15, 2020. The following scheme fills the schema table with the help of table 3 and multiplies that value by the tidal result from BIG. Then the calculation steps are carried out up to the VIII scheme, which refers to (Fadilah et al., 2014). Table 3 is the multiplier constant in Scheme II.

Table 3. Constants Multiplier Schematic II

\begin{tabular}{|c|c|c|c|c|c|c|c|c|c|c|c|c|c|c|c|c|c|c|c|c|c|c|c|c|}
\hline & \multicolumn{24}{|c|}{ Hour- } \\
\hline & 0 & 1 & 2 & 3 & 4 & 5 & 6 & 7 & 8 & 9 & 10 & 11 & 12 & 13 & 14 & 15 & 16 & 17 & 18 & 19 & 20 & 21 & 22 & 23 \\
\hline X1 & -1 & -1 & -1 & -1 & -1 & -1 & 1 & 1 & 1 & 1 & 1 & 1 & 1 & 1 & 1 & 1 & 1 & 1 & -1 & -1 & -1 & -1 & -1 & -1 \\
\hline Y1 & -1 & -1 & -1 & -1 & -1 & -1 & -1 & -1 & -1 & -1 & -1 & -1 & 1 & 1 & 1 & 1 & 1 & 1 & 1 & 1 & 1 & 1 & 1 & 1 \\
\hline $\mathrm{X} 2$ & 1 & 1 & 1 & -1 & -1 & -1 & -1 & -1 & -1 & 1 & 1 & 1 & 1 & 1 & 1 & -1 & -1 & -1 & -1 & -1 & 1 & 1 & 1 & 1 \\
\hline Y2 & 1 & 1 & 1 & 1 & 1 & 1 & -1 & -1 & -1 & -1 & -1 & -1 & 1 & 1 & 1 & 1 & 1 & 1 & 1 & -1 & -1 & -1 & -1 & -1 \\
\hline X4 & 1 & 0 & -1 & -1 & 0 & 1 & 1 & 0 & -1 & -1 & 0 & 1 & 1 & 0 & -1 & -1 & 0 & 1 & 1 & 0 & -1 & -1 & 0 & 1 \\
\hline Y4 & 1 & 1 & 1 & -1 & -1 & -1 & 1 & 1 & 1 & -1 & -1 & -1 & 1 & 1 & 1 & -1 & -1 & -1 & 1 & 1 & 1 & -1 & -1 & -1 \\
\hline
\end{tabular}

\subsection{Tidal Harmonic Components}

In this study, the tidal calculation using the Admiralty method produces nine harmonic components including Main lunar constituent (M2), Main solar constituent (S2), Lunar constituent (N2), Soli-lunar constituent (K2), Soli-lunar constituen (K1), Main lunar constituent (O1), Main solar constituen (P1), Main lunar constituent (M4), and Soli-lunar constituent (MS4). Table 4 shows the results of the calculation of the tidal harmonic components of November 1-15, 2020, in the waters of Bawean Island, East Java.

\begin{tabular}{cccccccccc}
\multicolumn{10}{c}{ Table 4. Harmonic Components } \\
\hline & M2 & S2 & N2 & K1 & O1 & M4 & MS4 & P1 & K2 \\
\hline $\mathbf{A}$ & 55.72241 & 63.69851 & 58.76568 & 30.14857 & 11.79347 & 13.53956827 & 18.085768 & 0.0118165 & 0.006768 \\
$\mathbf{g}^{\circ}$ & 110.5161 & 4.843616 & 247.16 & 151.627 & 101.318 & 289.3319735 & 119.99254 & 72 & 281.6 \\
\hline
\end{tabular}

From table 4 above, it can be seen that the results of the calculation of the harmonic components using the Admiralty method produce the principal components with the value of Amplitude (A) and Phase Difference $\left(\mathrm{g}^{\mathrm{o}}\right)$. The Formzahl number equation (equation 1) only uses four components, including O1, K1, M2 and S2 of the amplitude value to determine the tidal type. The table above shows that the amplitude values of O1, K1, M2 and S2 are 11.79347, 30.14857, 55.72241, and 63.69851, respectively. Then this value can be applied to equation 1 for the calculation of the Formzahl number.

\subsection{Determination of Tidal Type}

Determination of the tidal type by looking at the Formzahl number. If the value of F>3 is diurnal type, F < 0.25 is semidiurnal type, F $0.25-1.25$ is the mixed type with semidiurnal tendency and F $1.25-3.0$ is the mixed type with diurnal tendency. The results of data analysis processed in November 2020 show the Formzahl number of $0.3512(0.25<\mathrm{F}<1.5)$, which means that the waters on Bawean Island, Gresik Regency have a mixed type with a semidiurnal tendency (double daily). This type explains that there are two high tides and two low tides with almost the same height. The Bawean Island is one of the marine tourism and has a physiographical coastal environment that provides many tourist spots that need sea transportation capital, so this is very dependent on tidal conditions. It is known that semi-diurnal tidal conditions are very supportive of marine tourism activities, and the development of tourism activities also has great opportunities, especially in activities related to water activities.

\section{Conclusion}

From this study, it can be concluded that the tidal analysis using the Admiralty method produces nine components, including M2, S2, N2, K1, O1, M4, MS4, P1 and K2. The four components are the determinants of the tidal type, namely O1, K1, M2 and S2, with amplitude values of $11.79347,30.14857,55.72241$ and 63.69851. So the calculation using the Formzahl number equation yields a value of $0.3512(0.25<\mathrm{F}<1.5)$, which means that the tidal type on Bawean Island, East Java has a mixed type with a semidiurnal tendency (double daily). 


\section{Acknowledgments}

The author would like to thank BIG for providing tidal data.

\section{Referensi}

Ahmad, R., A. Hendri, dan M. Fauzi. (2017). Pengaruh Simulasi Awal Data Pengamatan Terhadap Efektivitas Prediksi Pasang Surut Metode Admiralty (Studi Kasus Pelabuhan Dumai). Jom FTEKNIK, 4(2): 1-10.

De Jong, C.D., I.A. Elema, G. Lachapelle, dan S. Skone. (2002). Hydrography. DUP Blue Print.

Dwikarsa, Y., and Prayogo M.L. (2021). Simulasi Penentuan Permukaan Air Laut Terendah pada Perencanaan Pelabuhan Menggunakan Software T_Tide. Juvenil, 2(3), 220-225. https://journal.trunojoyo.ac.id/juvenil

East Java Government. (2015). Laporan penyelenggara Pemerintah Daerah Provinsi Jawa Timur. In LPPD Jawa Timur (Vol. 1). https://jatimprov.go.id/ppid/uploads/berkasppid/LPPDProvJatim2015.pdf (Diakses pada 2 Februari 2021).

Fadilah., Suripin, dan D.P. Sasongko. (2014). Menentukan Tipe Pasang Surut dan Muka Air Rencana Perairan Laut Kabupaten Bengkulu Tengah Menggunakan Metode Admiralty. Maspari Journal, 6(1): 1-12.

Fitriana, D., N. Oktaviani, dan I.U. Khasanah. (2019). Analisa Harmonik Pasang Surut dengan Metode Admiralty pada Stasiun Berjarak Kurang dari $50 \mathrm{Km}$. Jurnal Meteorologi Klimatologi dan Geofisika, 6(1): 38-48. https://doi.org/10.36754/jmkg.v6i1.113.

Hamuna, B., R.H.R. Tanjung, J.D. Kalor, L. Dimara, E. Indrayani, M. Warpur, Y. Paulangan, dan K. Paiki. (2018). Studi Karakteristik Pasang Surut Perairan Laut Mimika, Provinsi Papua Studi Karakteristik Pasang Surut Perairan Laut Mimika, Provinsi Papua. Jurnal Acropora Ilmu Kelautan dan Perikanan Papua, 1(1):19-28.

Hasibuan, RD., H. Surbakti, dan R. Sitepu. (2015). Analisis Pasang Surut dengan Menggunakan Metode Least Square dan Penentuan Periode Ulang Pasang Surut dengan Metode Gumbel di Perairan Boom Baru dan Tanjung Buyut. Maspari Journal, 7(1), 35-48.

Khotip, M. T., A.D. Siswanto, dan Insafitri. (2016). Karakteristik Pasang Surut di Perairan Kalianget Kebupaten Sumenep. Prosiding Seminar Nasional Kelautan, 102-108.

Korto, J. (2015). Analisis Pasang Surut di Pantai Nuangan (Desa Iyok) Boltim dengan Metode Admiralty. Jurnal Sipil Statik, 3(6): 391-402.

Marine and Fisheries Ministry. (2016). Data Base Pulau-Pulau Kecil Jawa Timur. (Tidak Dipublikasikan).

Nurisman, N., Fauziyah, dan H. Surbakti. (2012). Karakteristik Pasang Surut di Alur Pelayaran Sungai Musi Menggunakan Metode Admirality. Maspari Journal, 4(1): 110-115.

Oktavia, R., J.I. Pariwono, dan P. Manurung. (2011). Variasi Muka Laut dan Arus Geostrofik Permukaan Perairan Selat Sunda Berdasarkan Data Pasut dan Angin Tahun 2008. Jurnal Ilmu dan Teknologi Kelautan Tropis, 3(2):127-152.

Ongkosongo. (1989). Pasang Surut (Pusat Penelitian dan Pengembangan Oseanologi (ed.)). Lembaga Ilmu Pengetahuan Indonesia. Jakarta.

Pariwono. (1989). Gaya Penggerak Pasang Surut (P. O. dan Suyarso (ed.)). Puslitbang Oseanologi LIPI. Jakarta.

Prayogo, M.L. (2021). Perbandingan Metode Admiralty dan Least Square untuk Analisis Pasang Surut di Pulau Mandangin Kabupaten Sampang, Jawa Timur. Jurnal Perikanan dan Kelautan, 10(2) : 59 - 69

Sangkop, N., J.D. Marnoto, dan M.I. Jasin. (2015). Analisis Pasang Surut di Pantai Bulo Desa Rerer Kecamatan Kombi Kabupaten Minahasa dengan Metode Admiralty. TEKNO, 13(63): 60-69.

Sukandar, S., C.S.U. Dewi, dan M. Handayani. (2017). Analisis kesesuaian dan daya dukung lingkungan untuk pengembangan wisata bahari di Pulau Bawean Kabupaten Gresik Provinsi Jawa Timur. Depik, 6(3): $205-213$. https://doi.org/10.13170/depik.6.3.7024.

Supriyadi, E., S.Siswanto, dan W.S. Pranowo. (2019). Karakteristik Pasang Surut di Perairan Pameungpeuk, Belitung, dan Sarmi Berdasarkan Metode Admiralty. Jurnal Meteorologi dan Geofisika, 19(1): 29-38. https://doi.org/10.31172/jmg.v19i1.518.

Triatmodjo, B. (2012). Perencanaan Bangunan Pantai (Vol. 2). Beta Offset. $327 \mathrm{hlm}$ . (2009). Perencanaan Pelabuhan. Beta Offset. 490 hlm 